\title{
Students' Beliefs and Attitudes Toward Learning in the Physics Component of the Lasallian (General Education) Core Curricu- lum
}

\author{
Anna Melissa Dalagan ${ }^{1}$ and Voltaire Mallari Mistades ${ }^{2 *}$ \\ ${ }^{1}$ College of Education, De La Salle University, Manila, Philippines. ${ }^{2}$ Physics Department, De La Salle Univer- \\ sity, Manila, The Philippines
}

Received: February 26, 2010 / Accepted: July 8, 2010

\begin{abstract}
I he Lasallian (General Education) Core Curriculum, implemented beginning Academic Year 2006-2007, aims to transform students' beliefs, attitudes, and emotional reactions by providing opportunities for students to reflect on their learning experiences. This study documented the effect of the physics component of the new curriculum on students' beliefs and attitudes by comparing the response profile of the freshmen of AY 2008-2009 with the response profile of the freshmen of AY 2005-2006 and AY 2006-2007. Pre- and Post-Course data was generated using the Maryland Physics Expectations Survey (MPEX) to determine students' "cognitive expectations" - the student's set of attitudes, beliefs, and assumptions about what sorts of things they will learn, what skills will be required, and what they will be expected to do in a physics class. Analysis of the results of the study revealed that the students moved towards an expert-like view in the Reality Link dimension and the Effort Link Dimension of the MPEX.
\end{abstract}

Keywords: Attitudes, Beliefs, Teaching and Learning, Introductory Physics, Curriculum.

* Corresponding author: voltaire.mistades@dlsu.edu.ph

\section{Introduction}

During Academic Year 2006-2007, De La Salle University, a private higher education institution in Manila, Philippines, began implementing the Lasallian (General Education) Core Curriculum. This new curriculum consists of a set of foundational, formative, and integrative courses that aim to "develop in students a critical appreciation of the diverse fields of human knowledge, their principles and science, and their arts and methods of inquiry" (Rapatan, et.al., 2005). The Lasallian (General Education) Core Curriculum is rooted on a transformative learning framework - a process of acquiring knowledge by synthesizing what is known with something that is not known through questioning assumptions, beliefs, and values and by considering multiple points of view, while always seeking to verify truth and reason. This process aims to transform a student's beliefs, attitudes, and emotional reactions by providing opportunities for the student to critically reflect on his/her learning experiences.

The Lasallian (General Education) Core Curriculum aims to expand the students' critical and creative thinking skills by engaging the students in various modes of inquiry. In the new curriculum, students are envisioned to develop knowledge as a result of their inquiry, action, and experimentation. Included in the core curriculum is a three-unit course on physics offered to students as one of their natural sciences courses. SCIENVP (Energy and the Environment - Physics track) focuses on the relationship between energy and the environment. It covers the study of the various 
sources of energy, the effects of using each energy source on man and his environment, and the pollution associated with energy consumption. The course aims to develop among students an awareness of their role to help protect and conserve the environment through the wise use of energy resources.

The University of Maryland Physics Education Research Group (UMPERG) puts forward the idea that what students expect will happen in their introductory college-level physics course plays a critical role in how they will respond to the course. The UMPERG coined the term "cognitive expectations" (Redish, et.al., 1998) to describe a student's set of attitudes, beliefs, and assumptions about what they will learn, what skills will be required, and what they will be expected to do in a physics class. To be able to document students' "cognitive expectations", the Maryland Physics Expectation Survey (MPEX) was developed and validated by the University of Maryland Physics Education Research Group.

The Maryland Physics Expectation Survey (MPEX) is a 34-item agree or disagree survey, which uses a five-point Likert scale, that probes attitudes, beliefs, and assumptions about physics. The six dimensions of learning physics that are probed by the MPEX are: independence, coherence, concepts, reality link, mathematics link, and effort Link.

The first three dimensions of the survey are taken from David Hammer's research (1994) on student's epistemological beliefs (Table 1). The three dimensions of learning that the Maryland Physics Education Research Group (UMPERG) added include

Table 1. Expert and Novice Views on Independence, Coherence, and Concepts Dimensions of Learning (Hammer, 1994).

\begin{tabular}{|l|l|l|}
\hline Dimensions of Learning & $\begin{array}{l}\text { Expert View } \\
\text { (favourable response) }\end{array}$ & $\begin{array}{l}\text { Novice View } \\
\text { (unfavorable response) }\end{array}$ \\
\hline $\begin{array}{l}\text { Independence } \\
\text { (beliefs and attitudes } \\
\text { about learning physics }\end{array}$ & $\begin{array}{l}\text { takes responsibility for } \\
\text { constructing her/his own } \\
\text { understanding; } \\
\text { learning involves an } \\
\text { active process of } \\
\text { constructing one's own } \\
\text { understanding }\end{array}$ & $\begin{array}{l}\text { takes what is given by } \\
\text { authorities (teacher, } \\
\text { textbook) without } \\
\text { evaluation; } \\
\text { learning is receiving } \\
\text { information }\end{array}$ \\
\hline $\begin{array}{l}\text { Coherence } \\
\text { (beliefs and attitudes } \\
\text { about the structure of } \\
\text { physics knowledge) }\end{array}$ & $\begin{array}{l}\text { physics needs to be } \\
\text { considered as a } \\
\text { connected consistent } \\
\text { framework }\end{array}$ & $\begin{array}{l}\text { physics is a collection of } \\
\text { isolated pieces; parts of } \\
\text { physics can be treated } \\
\text { as unrelated facts or } \\
\text { pieces }\end{array}$ \\
\hline $\begin{array}{l}\text { Concepts } \\
\text { (beliefs and attitudes } \\
\text { about the content of } \\
\text { physics knowledge) }\end{array}$ & $\begin{array}{l}\text { understand the } \\
\text { underlying ideas and } \\
\text { concepts }\end{array}$ & $\begin{array}{l}\text { focus on memorizing and } \\
\text { the use of formulas }\end{array}$ \\
\hline
\end{tabular}

(Table 2). Research has shown that students who engage in inquiry investigations significantly outperform students who were taught using the straight lecture method (Cheng, et.al., 2004; Hake, 1998; Marbach-Ad and Claassen, 2001; Marshall and Dorward, 2000; Thacker, et.al., 1994; Thornton and Sokoloff, 1998). Physics education research has likewise documented that interactive-engagement models and inquiry-based learning models, in comparison with the traditional passive lecture (transmission) model (McDermott and Redish, 1999), allowed students to construct more appropriate representations of physical phe-
Table 2. Expert and Novice Views on Reality Link, Math Link, and Effort Link (Redish, et. al., 1998).

\begin{tabular}{|l|l|l|}
\hline $\begin{array}{l}\text { Dimensions of } \\
\text { Learning }\end{array}$ & $\begin{array}{l}\text { Expert View } \\
\text { (favourable } \\
\text { response) }\end{array}$ & $\begin{array}{l}\text { Novice View } \\
\text { (unfavourable } \\
\text { response) }\end{array}$ \\
\hline $\begin{array}{l}\text { Reality Link } \\
\text { (beliefs and } \\
\text { attitudes about the } \\
\text { connection between } \\
\text { physics and reality) }\end{array}$ & $\begin{array}{l}\text { ideas learned in } \\
\text { physics are relevant } \\
\text { and useful in a wide } \\
\text { variety of real } \\
\text { contexts }\end{array}$ & $\begin{array}{l}\text { ideas learned in } \\
\text { physics have little } \\
\text { relation to } \\
\text { experiences outside } \\
\text { the classroom }\end{array}$ \\
\hline $\begin{array}{l}\text { Math Link } \\
\text { (beliefs and } \\
\text { attitudes about the } \\
\text { role of mathematics } \\
\text { in learning physics) }\end{array}$ & $\begin{array}{l}\text { considers } \\
\text { mathematics as a } \\
\text { suitable way of } \\
\text { representing } \\
\text { physical phenomena }\end{array}$ & $\begin{array}{l}\text { views physics and } \\
\text { math as } \\
\text { independent of } \\
\text { each other, with } \\
\text { little relationship } \\
\text { between them }\end{array}$ \\
\hline $\begin{array}{l}\text { Effort Link } \\
\text { (beliefs and } \\
\text { attitudes about the } \\
\text { kind of activities } \\
\text { and work necessary } \\
\text { to make sense out } \\
\text { of physics) }\end{array}$ & $\begin{array}{l}\text { makes the effort to } \\
\text { use available } \\
\text { information and } \\
\text { feedback to make } \\
\text { sense out of physics }\end{array}$ & $\begin{array}{l}\text { does not attempt to } \\
\text { use available } \\
\text { information and } \\
\text { feedback } \\
\text { effectively }\end{array}$ \\
\hline
\end{tabular}

nomena.

The objective of this study was to document how the new curriculum, which utilized the inquiry-based learning models described above, influenced students' beliefs and attitudes toward learning. The respondents of the present study are the freshman students of Academic Year (AY) 2008-2009, which corresponds to the third year of implementation of the new curriculum. Using the Maryland Physics Expectations Survey (MPEX) developed by the University of Maryland Physics Education Research Group (Redish, et.al., 1998), the beliefs and attitudes of the students were documented. The study compared the response profile of the freshmen of AY 2008-2009 with the response profile of the freshmen of AY 2005-2006 (Mistades, 2006) and AY 20062007 (Mistades, 2007). The results of the study will aid in providing a picture of the transformative learning framework as utilized in the physics component of the Lasallian (General Education) Core Curriculum. The study will likewise provide curriculum planners with feedback regarding which areas of the curriculum need to be strengthened, improved, retained, or removed.

\section{Research Method}

During the first class session, the researchers administered the Maryland Physics Expectation Survey (MPEX) to the students who participated in the study. This set of data is tagged as the "pre-course" data. During final examinations week, the researchers again administered the Maryland Physics Expectation Survey (MPEX) to the students in order to generate the "postcourse" data.

The students' response for each item in the MPEX was then compared with the "experts' response". In order to develop the instrument's answer key, Redish, et.al. (1998) conducted consultations with lifelong learners -- experienced physics instructors who have a high concern for educational issues and a high sensitivity to students. In presenting the MPEX data, students' responses are coded as either favourable (in agreement with the experts' response) or unfavourable (not in agreement with the experts' 
response). Redish, et.al. (1998) put forward the use of a Gaussian approximation to the binomial distribution in order to determine if a difference or shift in the average percentage response is significant. For large populations ( $\mathrm{r}=450$ students), a shift of $5 \%$ is considered significant; for smaller populations, a $10 \%$ shift may be considered significant.

\section{Discussion of Results}

Tables 3, 4, and 5 present the Maryland Physics Expectations Survey (MPEX) profile of the respondents. For each group of students, we show the summary of the students' agreement with the expert response (favourable responses) and disagreement with the expert response (unfavourable responses) in each of the six dimensions of learning probed by the MPEX. We also provide the difference in the pre-course and post-course responses for each dimension of learning. A negative difference means the pre-course response rating is higher than the post-course rating. Ideally, the differences between pre-course and post-course responses in the Favourable Response column should be positive.

\section{Independence Dimension}

This dimension looks at how students think they acquire knowledge and understanding in physics and whether they are solely dependent on their professor and textbook or believe they could develop it on their own. If the students believe the latter, they are more likely to take responsibility for their own learning. The data gathered for this cluster showed a slight increase $(4.4 \%)$ in the favourable responses of the Liberal Arts majors (Table 5), while for both the Business and Economics majors (Table 3) and

Table 3. MPEX Profile of College of Business and Economics students ( $\mathrm{n}=104)$.

\begin{tabular}{|l|l|l|l|l|l|l|}
\cline { 2 - 7 } \multicolumn{1}{c|}{} & Favourable Response & \multicolumn{3}{l|}{ Unfavourable Response } \\
\hline $\begin{array}{l}\text { Dimensions of } \\
\text { Learning Physics }\end{array}$ & $\begin{array}{l}\text { Pre-course } \\
\text { Response }\end{array}$ & $\begin{array}{l}\text { Post-course } \\
\text { Response }\end{array}$ & $\begin{array}{l}\text { Difference between } \\
\text { pre-and post-course } \\
\text { response }\end{array}$ & $\begin{array}{l}\text { Pre-course } \\
\text { Response }\end{array}$ & $\begin{array}{l}\text { Post-course } \\
\text { Response }\end{array}$ & $\begin{array}{l}\text { Difference between } \\
\text { pre-and post-course } \\
\text { response }\end{array}$ \\
\hline Independence & $41.9 \%$ & $40.0 \%$ & $-1.9 \%$ & $31.5 \%$ & $36.4 \%$ & $4.9 \%$ \\
\hline Coherence & $31.4 \%$ & $30.0 \%$ & $-1.4 \%$ & $43.1 \%$ & $47.1 \%$ & $4.0 \%$ \\
\hline Concepts & $31.6 \%$ & $28.9 \%$ & $-2.7 \%$ & $46.6 \%$ & $51.9 \%$ & $5.3 \%$ \\
\hline Reality Link & $61.3 \%$ & $55.3 \%$ & $-6.0 \%$ & $15.4 \%$ & $24.5 \%$ & $9.1 \%$ \\
\hline Math Link & $48.2 \%$ & $43.3 \%$ & $-4.9 \%$ & $28.7 \%$ & $34.9 \%$ & $6.2 \%$ \\
\hline Effort link & $73.7 \%$ & $74.6 \%$ & $0.9 \%$ & $10.8 \%$ & $11.7 \%$ & $-0.9 \%$ \\
\hline
\end{tabular}

Table 4. MPEX Profile of College of Education students $(n=58)$.

\begin{tabular}{|l|l|l|l|l|l|l|}
\cline { 2 - 7 } \multicolumn{1}{c|}{} & Favourable Response & \multicolumn{3}{l|}{ Unfavourable Response } \\
\hline $\begin{array}{l}\text { Dimensions of } \\
\text { Learning Physics }\end{array}$ & $\begin{array}{l}\text { Pre-course } \\
\text { Response }\end{array}$ & $\begin{array}{l}\text { Post-course } \\
\text { Response }\end{array}$ & $\begin{array}{l}\text { Difference between } \\
\text { pre-and post- } \\
\text { course response }\end{array}$ & $\begin{array}{l}\text { Pre-course } \\
\text { Response }\end{array}$ & $\begin{array}{l}\text { Post-course } \\
\text { Response }\end{array}$ & $\begin{array}{l}\text { Difference between } \\
\text { pre-and post- } \\
\text { course response }\end{array}$ \\
\hline Independence & $36.3 \%$ & $33.6 \%$ & $-2.7 \%$ & $37.3 \%$ & $42.7 \%$ & $5.4 \%$ \\
\hline Coherence & $33.6 \%$ & $28.1 \%$ & $-5.5 \%$ & $42.4 \%$ & $45.4 \%$ & $3.0 \%$ \\
\hline Concepts & $25.1 \%$ & $26.3 \%$ & $1.2 \%$ & $49.4 \%$ & $51.7 \%$ & $2.3 \%$ \\
\hline Reality Link & $57.6 \%$ & $58.5 \%$ & $0.9 \%$ & $21.2 \%$ & $22.0 \%$ & $0.8 \%$ \\
\hline Math Link & $47.2 \%$ & $42.4 \%$ & $-4.8 \%$ & $29.9 \%$ & $34.8 \%$ & $4.9 \%$ \\
\hline Effort Link & $71.9 \%$ & $73.2 \%$ & $1.3 \%$ & $10.2 \%$ & $11.5 \%$ & $1.3 \%$ \\
\hline
\end{tabular}

Table 5. MPEX Profile of College of Liberal Arts students $(n=92)$.

\begin{tabular}{|l|l|l|l|l|l|l|}
\cline { 2 - 7 } \multicolumn{1}{c|}{} & Favourable Response & \multicolumn{3}{l|}{ Unfavourable Response } \\
\hline $\begin{array}{l}\text { Dimensions of } \\
\text { Learning Physics }\end{array}$ & $\begin{array}{l}\text { Pre-course } \\
\text { Response }\end{array}$ & $\begin{array}{l}\text { Post-course } \\
\text { Response }\end{array}$ & $\begin{array}{l}\text { Difference between } \\
\text { pre-and post- } \\
\text { course response }\end{array}$ & $\begin{array}{l}\text { Pre-course } \\
\text { Response }\end{array}$ & $\begin{array}{l}\text { Post-course } \\
\text { Response }\end{array}$ & $\begin{array}{l}\text { Difference between } \\
\text { pre-and post- } \\
\text { course response }\end{array}$ \\
\hline Independence & $37.6 \%$ & $42.0 \%$ & $4.4 \%$ & $31.1 \%$ & $31.3 \%$ & $0.2 \%$ \\
\hline Coherence & $30.2 \%$ & $31.5 \%$ & $1.3 \%$ & $39.1 \%$ & $41.3 \%$ & $2.2 \%$ \\
\hline Concepts & $26.5 \%$ & $30.1 \%$ & $3.6 \%$ & $46.7 \%$ & $48.2 \%$ & $1.5 \%$ \\
\hline Reality Link & $56.5 \%$ & $59.0 \%$ & $2.5 \%$ & $16.0 \%$ & $18.5 \%$ & $2.5 \%$ \\
\hline Math Link & $43.5 \%$ & $46.7 \%$ & $3.2 \%$ & $26.1 \%$ & $27.5 \%$ & $1.4 \%$ \\
\hline Effort Link & $69.8 \%$ & $72.4 \%$ & $2.6 \%$ & $11.3 \%$ & $11.3 \%$ & $0 \%$ \\
\hline
\end{tabular}

the Education majors (Table 4), the data reveals a decrease in their favourable responses: $1.9 \%$ decrease and $2.7 \%$ decrease, respectively.

Looking at the two items in this dimension that had the lowest favourable response, the students' low favourable response (Education majors, 22\%; Liberal Arts majors, 31\%; and Business and Economics majors, 36\%; expert response is disagree) to MPEX item \# 27, "Understanding physics basically means being able to recall something you've read or been shown" reveals that the majority of students simply depended on the examples shown in books or solved by their teachers in class.

The overall decrease in favourable responses by the Education majors and the Business and Economics majors may be due to how they responded to MPEX item \# 14, "Learning physics is a matter of acquiring knowledge that is specifically located in the laws, principles, and equations given in class and/or in the textbook". Seventy-one percent of the Education majors and seventy-five percent of the Business and Economics majors said they agree with the statement, which is contrary to the experts' response. The experts who were surveyed disagreed with the statement since they believe that learning physics should go beyond what is written in the textbook.

For the College of Liberal Arts students, the results of the present study mirror our previous results (Mistades, 2007) for the freshmen of Academic Year 2005-2006, which is a 3\% upward shift in their agreement with the experts' response. The Liberal Arts majors of Academic Year 2006-2007 posted a 4.4\% increase in their favourable responses for the Independence dimension. On the other hand, the slight decrease of $1.9 \%$ in the favourable responses of the Business and Economics majors for the present study contradicts the $3 \%$ and $4 \%$ increase in favourable responses reported during Academic Year 2005-2006 and 2006-2007, respectively.

\section{Coherence Dimension}

The Coherence dimension looks at the students' beliefs about the structure of physics knowledge and whether they see it as a collection of isolated pieces or as a single coherent system. Most often, students would see science as a collection of facts but fail to see how the facts relate with each other. The students' response to MPEX item \# 12 (expert response is disagree), 
"Knowledge in physics consists of many pieces of information each of which applies primarily to a specific situation", reveals that the students have not yet moved from a novice view of learning to a more expert-like view. Eighty-three percent of the Education majors, $86 \%$ of the Business and Economics majors, and $80 \%$ of the Liberal Arts majors agreed with this statement, which is contrary to the experts' response.

For this dimension, with a pre-course response of $30.2 \%$ and a post-course response of $31.5 \%$, only a slight increase was reported for the College of Liberal Arts students. As this shift in favourable responses is less than $10 \%$, following the recommendation of Redish, et.al. (1998), it could not be considered as statistically significant. We hypothesize that the downward shift in favourable responses of the Education majors (33.6-28.1\%) and Business and Economics majors (31.4-30.0\%) may be attributed to the new activities tried-out during the Academic Year 08-09. It is possible that the students from these two groups did not see how the activities on weather patterns, solar radiation, and the greenhouse effect relate to the earlier topics on force and motion. Thus, we recommend that teachers who are handling core curriculum courses should clearly articulate the relationship between the concepts learned.

The percentages of post-course favourable responses reported by the current study (Business \& Economics, 30.0\%; Liberal Arts, $31.5 \%$ ) are similar to those previously reported by our group Mistades (2007) for Academic Year (AY) 2005-2006 (Business \& Economics, 29\%; Liberal Arts, 26\%) and AY 20062007 (Business \& Economics, 35\%; Liberal Arts, 36\%). This observation leads us to hypothesize that An Introductory Physics class may not be enough to shift a freshman student's learning style from looking at individual concepts to finding relationships between concepts learned.

\section{Concepts Dimension}

The Concepts dimension profiles the students' beliefs about the content of physics knowledge and whether the students see knowledge only as equations and formulas or realize that concepts underlie each formula. The students' response to MPEX item \# 26, "When I solve exam or homework problems, I think about the concepts that underlie the problem," provided us with a glimpse that the students are beginning to transition from their novice view to an expert-like view. Four out of five students (79\% of the Education majors, $86 \%$ of the Liberal Arts majors, and $80 \%$ of the Business and Economics majors) reported that they agree with the statement, which is the same response given by the experts who were surveyed.

Although the students are beginning to transition to become expert-like thinkers in the Concepts dimension, their over-all unfavourable response for this dimension (Business \& Economics majors, $51.9 \%$; Education majors, $51.7 \%$; Liberal Arts majors, $48.2 \%$ ) shows that students continue to see physics as a "substitute-the-given-and-solve-mathematically" type of course and that the concepts underlying the problems are mostly overlooked. We note that for this cluster, students from all three colleges gave the most number of unfavourable responses to MPEX item \# 19, "The most crucial thing in solving a physics problem is finding the right equation to use". The expert response is disagree, but $84 \%$ of the Business \& Economics majors, $85 \%$ of the Education majors, and $88 \%$ of the Liberal Arts majors said they agree with the statement.

In our previous study (Mistades, 2007) we reported a statistically significant increase $14 \%$ for the College of Liberal Arts and $15 \%$ for the College of Business and Economics) for this dimension for the freshman of Academic Year 2006-2007, reflective of the students' conscious effort in learning the basic concepts that underlie the study of physics.

\section{Reality Link Dimension}

The Reality Link dimension determines the students' beliefs about the connection between physics and reality and whether physics is unrelated to experiences outside the classroom or it is useful to think about them together. This dimension is one of the two dimensions that received a favourable response greater than 50\%. MPEX item \# 18 (expert response is agree) received the highest number of favourable response across the three colleges. This item states that, "To understand physics, it is sometimes necessary to think about my personal experiences and relate them to the topic being analyzed", and three out of four students agreed with this statement $170 \%$ of the Business and Economics majors, $78 \%$ of the Education majors, and $74 \%$ of the Liberal Arts majors) showing an expert-like belief for this item.

Even in the negatively-worded item \# 22 (expert response is disagree), "Physics is related to the real world, but it is rarely essential to think about the connection in doing what is needed to be done in a Physics course", a majority of students (College of Education, 58\%; College of Liberal Arts 54\%; College of Business and Economics, 59\%) disagreed with the statement, thus strengthening our observation that the students are moving from a novice-like view to an expert-like view of learning in the Reality Link dimension.

Although the Reality Link dimension responses obtained a difference of less than 10\% when comparing the post-course data and the pre-course data, it is worth noting that majority of the students responded favourably with an average percentage of $57.6 \%$ showing the students' awareness of the link between ideas learned in their physics class and their experiences in the real world.

The data gathered in this study is an improvement from the data for the Reality Link dimension during AY 2006-2007 (Mistades, 2007), where the Liberal Arts majors posted a $46.9 \%$ favourable response and the Business and Economics majors reported a $46.4 \%$ agreement with the experts' response. We attribute this improvement to the introduction of additional realworld examples that the students are able to relate with their own experiences.

\section{Math Link Dimension}

The Math Link dimension verifies the students' beliefs about the role of mathematics in learning physics and whether they see the mathematical formalism as just a tool used to calculate numbers or as a way of representing information about physical 
phenomena. It is important for students to see the link between the mathematical representation and the physical phenomena in order to develop the ability to use abstract and mathematical reasoning in describing and making predictions about the behaviour of real physical systems. The novice-like view in the favourable response profile (College of Education, 42.4\%; College of Liberal Arts 46.7\%; College of Business and Economics, $43.3 \%$ ) reveals that the students have not yet seen the deeper physical relationship present in the equations. The data in this dimension support the findings of the Concepts Dimension, where the students view their physics course as a "substitute-the-givenand-solve-mathematically" type of process.

\section{Effort Link Dimension}

The Effort Link dimension looks at students' beliefs about the kind of activities and work necessary to make sense out of physics and whether students expect to think carefully and evaluate what they are doing based on available material and feedback or not. A favourable response would reflect a student's willingness to make the necessary effort to make sense out of the topics in physics. Across the three colleges, the most number of favourable responses was reported for the same statement, MPEX item \# 3 (expert response is agree), "Students should go over their class notes carefully to prepare for test in a Physics course". The Education, Business and Economics, and Liberal Arts majors agreed with this statement with a favourable percentage of $90 \%, 97 \%$, and $96 \%$, respectively.

The percentages of post-course favourable responses reported by the current study (Business \& Economics, 74.6\%; Liberal Arts, $72.4 \%$; Education, $73.2 \%$ ) show that the course was able to persuade students to see the importance of exerting effort to make sense out of physics. The majority of students have responded that the effort they exert in learning physics is similar to the effort exerted by the life-long learners (experts) interviewed by Redish et.al. (1998). The results reported in this study [an increase in the percentage of students giving a favourable response] differ from the results obtained by Redish et.al. (1998) in their original study where they found a downward shift in the effort the students exerted. Similar to what this present study obtained, Van Aalst and Key (2000) also reported a positive change in the effort link dimension for the students they surveyed. Our previous study (Mistades, 2007) also reported a positive trend in the responses of the groups surveyed during Academic Year 2005-2006 and AY 2006-2007.

\section{Conclusion}

The data gathered during Academic Year 2008-2009, the third year of implementation of the Introductory Physics component of the Lasallian General Education Core Curriculum, reveal both positive gains and downward shifts in students' beliefs and attitudes towards learning physics. The responses of the students who were surveyed reflected agreement with the "experts' response" in the Effort Link dimension and the Reality Link dimension of the Maryland Physics Expectations (MPEX) Survey. The students reported they were exerting the effort required of them that will allow them to understand physics. The positive gain in the Reality Link dimension is attributed to the introduction of additional real-world examples with which the students can associate their personal experiences. The students' profile in the Concepts and Coherence dimensions, however, points out the need to strengthen the students' grasp of the physics concepts and their relationship to one another. Having the students prepare "cognitive maps" or "concept maps" will strengthen their beliefs and attitudes about the structure of physics knowledge as a consistent, connected framework.

\section{Acknowledgement}

The authors are very grateful to the support extended by the Physics Department of De La Salle University Manila and to the comments and suggestions of the two anonymous reviewers of this paper.

\section{References}

Cheng K, B Thacker, and R Cardenas (2004) Using an on-line homework system enhances students' learning of physics concepts in an introductory physics course. American Journal of Physics 72(12): 1447-1453.

Hake R (1998) Interactive-engagement vs. traditional methods: A sixthousand-student survey of mechanics test data for introductory physics courses. American Journal of Physics 66(1): 64-74.

Hammer D (1994) Epistemological beliefs in introductory physics. Cognition and Instruction 12: 151-183.

Marbach-Ad G and L Claassen (2001) Improving students' questions in inquiry labs. The American Biology Teacher 63(3): 410-419.

Marshall J and J Dorward (2000) Inquiry experiences as a lecture supplement for pre-service elementary teachers and general education students. Physics Education Research American Journal of Physics supplement 68(7): S27-S36.

McDermott L and E Redish (1999) Resource Letter: PER-1: Physics Education Research. American Journal of Physics 67(9); 755-767.

Mistades V (2006) Cognitive expectations in Introductory Physics: A Profile of Biology, Liberal Arts, and Physics majors. Journal of Research in Science, Computing, and Engineering 3(2): 24-29.

Mistades $V$ (2007) Student expectation in a general education physics course taught using a transformative-learning paradigm. INTI Journal Special Issue on Teaching and Learning 1(1): 149-160.

Rapatan M, M Zamora, O Malabanan, A Limjap, L Razon, and V Mistades (2005) "Towards a Lasallian Pedagogical Framework of Transformative Learning ", De La Salle University, Manila.

Redish E, J Saul, and R Steinberg (1998) Student expectations in introductory physics. American Journal of Physics 66(3): 21 2-224.

Thacker B, E Kim, K Trefz, and S Lea (1994) Comparing problem solving performance of physics students in inquiry-based and traditional introductory physics courses. American Journal of Physics 62(6): 627633.

Thornton R and D Sokoloff (1998) Assessing student learning of Newton's laws: The force and motion conceptual evaluation and the evaluation of active learning laboratory and lecture curricula. American Journal of Physics 66(3): 338-352.

van Aalst J and T Key (2000) Pre-professional students' beliefs about learning physics. Canadian Journal of Physics 78(1): 73-78. 
Appendix. Learning Activities for the General Education Course on Energy and the Environment.

\begin{tabular}{|c|c|}
\hline Introductory Topics & Learning Activities \\
\hline $\begin{array}{l}\text { Work, Energy, and Power } \\
\text { A. Work and Power } \\
\text { B. Different types of Energy } \\
\text { C. Conservation of Energy (Transformation } \\
\text { of Energy) } \\
\text { D. Sources of Energy }\end{array}$ & 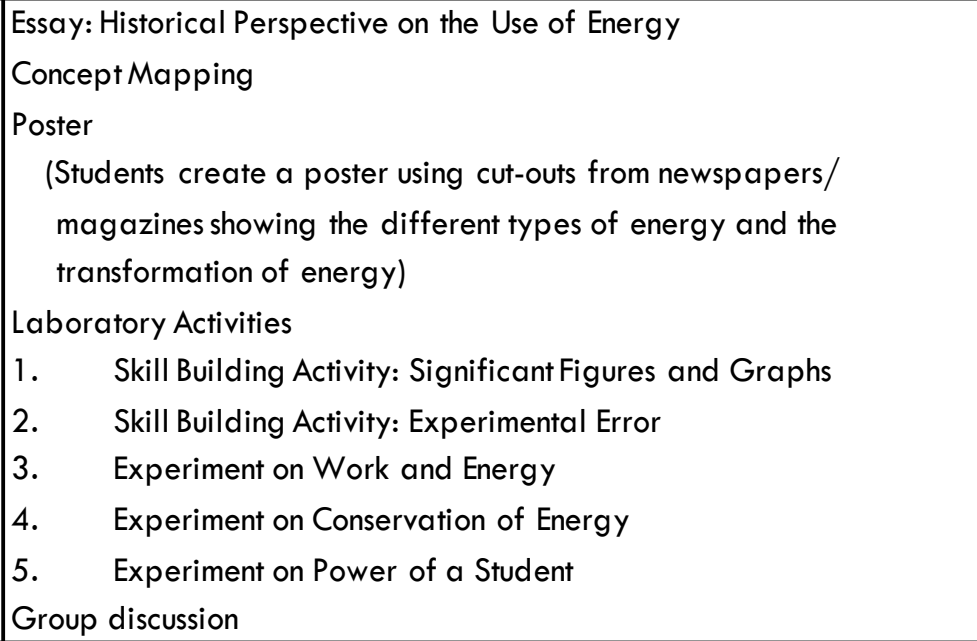 \\
\hline Enabling Topics & Learning Activities \\
\hline Electrical Energy & $\begin{array}{l}\text { Getting to know your electric bill } \\
\text { Demonstration on how electricity is generated } \\
\text { Laboratory Activity } \\
1 . \quad \text { Experiment on Potato Battery }\end{array}$ \\
\hline Heat Energy & $\begin{array}{l}\text { Laboratory Activity on Calorimetry } \\
\text { 1. } \quad \text { Specific Heat of Solids } \\
2 . \quad \text { Heat of Fusion/Heat of Vaporization } \\
\text { Group discussions } \\
\text { Essay on the role of specific heat capacity and latent heats on weather }\end{array}$ \\
\hline Methods of Heat Transfer & $\begin{array}{l}\text { Laboratory activity on the different methods of heat transfer } \\
\text { 1. Experiment on Heat Transfer by Conduction and Radiation } \\
\text { Group discussion } \\
\text { Essay/report about the Physics of the Greenhouse Effect }\end{array}$ \\
\hline Culminating Topic & Learning Activities \\
\hline Dynamics of the Atmosphere & $\begin{array}{l}\text { Laboratory Activity on Radiation and Seasons } \\
\text { 1. Experiment on Incoming Solar Radiation and Seasons } \\
\text { Group discussions }\end{array}$ \\
\hline Greenhouse Effect and Global Warming & $\begin{array}{l}\text { Film Viewing: An Inconvenient Truth, The } 11^{\text {th }} \text { Hour, } \\
\qquad \text { Climate Gate } \\
\text { Essay/Reflection Paper about the Film } \\
\text { Laboratory Activity: Computer Simulation } \\
\text { 1. Weather's Role/ Tracking Ozone } \\
\text { 2. Smog City }\end{array}$ \\
\hline & Group Presentation on Sources of Energy \\
\hline
\end{tabular}

